\title{
A Study on Work-related Stress among the Teachers and Administrators of Privately Managed Business Schools in West Bengal
}

\author{
Pijus Kanti Bhuin \\ Asst. Professor, Rural Management, Dept. of Commerce, Bhatter College, Dantan, Paschim Medinipur, \\ West Bengal, India. Orcid: 0000-0001-8961-4161. Email:pk_bhuin@yahoo.com
}

\begin{abstract}
Studies have revealed that teaching is one of the stressful occupations worldwide. Competitive stature of globalized education market has been changing in a dynamic business environment. Private players are coming up rapidly to meet up the skills and knowledge gap being equipped with better physical infrastructure, corporate management structure and business intelligence system. In this context, an investigation is made on how do the educators involved in private management educational institutes experience work-stress with respect to few demographic and job factors. Survey for the study is conducted using a validated stress scale among the teachers and academic administrators of private educational institutes in West Bengal, India. Results reveal that nearly one third of the respondents are exposed to high stress zone. Situation is alarming, not parlous though. ANOVA results show that age, experience and area of residence are most powerful endogenous factor in differentiating work-groups in respect to stress. Gender, income, job status and educational qualifications have comparatively lower influences. Interestingly, teachers and administrators do not differ themselves significantly so far work-related stress is concerned. Research findings will help the policy maker examining the existing pattern of work stress and its likely implications in designing institutional human resource policy and practices.
\end{abstract}

Keywords: Business Intelligence System, Corporate Management, Human Resource Policy, Job Role, Work-Stress

\section{Prologue}

There was only one management institute in West Bengal in the early 50's, namely, the Indian Institute of Social Welfare and Business Management (IISWBM), Kolkata and thereafter in early 60's, the Indian Institute of Management Calcutta (IIM-C) was established. Today, total number of approved institutions conducting MBA courses is 56 with intake capacity of roughly 5000 students (Annual Report 2012-13, HED, Govt. of WB). With the rapid growth of the educational institutes, Bengal is, interestingly, experiencing a regressive demand for management programmes. Pace of industrial growth and employment opportunities are showing a declining rate in West Bengal during the last couple of decades. Students from affluent families prefer opting their management education from southern/western part of India or abroad expecting better job opportunities. Crisis of the quality students' admissions into private Bschools in West Bengal sets a new challenge for them fueling up the virtuous cycle of growth and survival. Consequently, faculty members and administrators being stakeholders of these institutions are facing the problems of career growth and advancements. This issue induces to investigate whether teachers as well as administrators are exposed to work related stress or not.

Very few studies were found on teachers stress in Eastern and North-Eastern parts of India. Keeping in view the gaps in research, the present study aims to understand the stress phenomena among the educators of the private higher educational institutes of West Bengal in the light of few demographics and job attributes. 


\section{Review of Literature}

Hans Selye (1956) defined Stress "as any external events or internal drive which threatens to upset the organismic equilibrium". National Institute of Occupational Safety and Health (NIOSH) wrote in 1999, "Work stress as being the harmful and emotional responses that occur when the requirements of the job do not match the capabilities, resources, or needs of the worker". Stress results from confronting an opportunity, constraint or demand, when the expected outcome is important and uncertain (Robbins and Sanghi, 2006). Occupational stress is a global phenomenon today. Employees, basically in the underdeveloped countries have never seen the new face of work-environment - strenuous and stressful. Studies have consistently concluded that teaching is a stressful occupation, and that a significant number of teachers, perhaps even a majority, are affected by work-related stress (Rudow, 1999; Dunham, 1998; Kyriacou, 1999, 2000, 2001; Guglielmi and Tatrow, 1998).

Teachers' stress has been reportedly greater than that for the general population (Tuettemann \& Punch, 1992). Mushroom growth of self-financing educational institutions has changed the organizational climate at the institutions (Devi and Velayudham, 2003). Reddy and Poornima (2012), have shown that majority $(74 \%)$ of the university teachers are experiencing moderate and high level of stress and $86 \%$ of teachers have professional burnout. They also found that there is a positive relationship between the occupational stress and professional burnout among the university teachers. Inadequate salary is the primary factor causing stress followed by inadequate resource and facilities, and problems with superiors and peers (Jagadeesh, 2013)

Sing and Rani (2015) show in a study in Haryana that stress reduces teachers' efficiency and effectiveness due to mood disturbance, psychological distress, anxiety, lowered morale, cardiovascular disease and fatigue. Kayastha and Kayastha (2012) studied in Nepal and found significant relationship between high level of occupational stress and low level of job satisfaction.

Teachers' stress not only affects his/her own health but also negatively affects the students and even the organisation. Studies among teachers have indicated that stress has alarming negative effects on their psychological, physical and behavioural responses The negative effects include irritability, anger, fatigue, anxiety, depression, headaches, loss of concentration, sleep disturbances, persistent negative thoughts, low appetite, gastrointestinal problems, musculoskeletal problems, blood pressure, heart disease, stroke, cancer, suicide, etc. to highlight a few from the exhaustive list (Nagra \& Arora, 2013).

Existing literatures admit the prevalence of work stress among the teachers engaged in Indian higher education sector with varying magnitude and dimensions. Questions raised in the current paper as - is the work-related stress prevalent among the management teachers and administrators of private management educational institutes in West Bengal? If so, what is the nature? Subsequently, how do the different demographic variables and job attributes influence the different groups of employees on account of work-related stress?

\section{Objectives of the Study}

1. To explore the nature of work-related stress prevalent among the teachers and academic administrators of privately managed Business schools.

2. To find out the difference of work-related stress-experience with respect to demographics and job attributes amongst the teachers and administrators.

\section{Hypothesis}

The analysis is carried out considering eight demographic variables, viz., age, gender, service experience, marital status, income, educational qualifications, area of residence and status in family, and three job-related variables - work positions, job status and additional responsibility. Hypothesis for the objective 2 which aims to find out the difference of work stress across the sub-groups of eleven test variables are presented in Table 1. 


\begin{tabular}{|c|c|c|c|}
\hline \# & $\begin{array}{l}\text { Test of Hypothesis } \\
\text { for }\end{array}$ & Null Hypothesis $\left(\mathrm{H}_{0}\right)$ & $\begin{array}{c}\text { Alternative } \\
\text { Hypothesis }\left(\mathrm{H}_{1}\right)\end{array}$ \\
\hline 1 & Gender & $\begin{array}{l}\text { There exists no difference of stress experience between male } \\
\text { and female respondents }\end{array}$ & Ho is not true \\
\hline 2 & Age-group & $\begin{array}{l}\text { There exists no difference of stress experience among young, } \\
\text { middle-aged and post middle aged respondents }\end{array}$ & Ho is not true \\
\hline 3 & Work-Position & $\begin{array}{l}\text { There exists no difference of stress experience between } \\
\text { teachers and Administrators }\end{array}$ & Ho is not true \\
\hline 4 & $\begin{array}{l}\text { Service } \\
\text { Experience }\end{array}$ & $\begin{array}{l}\text { There exists no difference of stress experience among } \\
\text { respondents having below } 10 \text {-year, } 10 \text { to } 20 \text { year and above } 20 \text { - } \\
\text { year of service experience }\end{array}$ & Ho is not true \\
\hline 5 & Marital Status & $\begin{array}{l}\text { There exists no difference of stress experience among married, } \\
\text { unmarried and widowed/divorced respondents }\end{array}$ & Ho is not true \\
\hline 6 & Job Status & $\begin{array}{l}\text { There is no difference of work stress among the respondents } \\
\text { holding regular, probation/ad-hoc and guest/visiting/part-time job } \\
\text { status }\end{array}$ & Ho is not true \\
\hline 7 & $\begin{array}{l}\text { Additional } \\
\text { Responsibilities }\end{array}$ & $\begin{array}{l}\text { There exists no difference of stress experience between the } \\
\text { respondents having additional responsibilities and not having } \\
\text { additional responsibilities }\end{array}$ & Ho is not true \\
\hline 8 & Area of Residence & $\begin{array}{l}\text { There exists no difference of stress experience among Rural, } \\
\text { Urban and semi-urban respondents }\end{array}$ & Ho is not true \\
\hline 9 & Income & $\begin{array}{l}\text { Experience of stress is indifferent to the four annual salary } \\
\text { groups }\end{array}$ & Ho is not true \\
\hline 10 & $\begin{array}{l}\text { Educational } \\
\text { Qualifications }\end{array}$ & $\begin{array}{l}\text { Work-stress is indifferent to level of educational qualifications } \\
\text { (PhDs and Non-PhDs) }\end{array}$ & Ho is not true \\
\hline 11 & Status in Family & $\begin{array}{l}\text { There exists no difference of stress experience between head of } \\
\text { a family and member of a family }\end{array}$ & Ho is not true \\
\hline 12 & $\begin{array}{l}\text { Work-Position and } \\
\text { Service } \\
\text { Experience }\end{array}$ & $\begin{array}{l}\text { There is no difference in influence of service experience on work } \\
\text { stress between the teachers and Administrators }\end{array}$ & Ho is not true \\
\hline
\end{tabular}

\section{Research Methodology}

Sampling: Sample units were selected from the population of 45 privately managed institutes offering regular post graduate management programmes in West Bengal, using stratified purposive sampling technique. On an average $12-13$ faculty members per institute constitute approximately 550 population units. Sample size for the study is approximately $20 \%$ of the population size, i.e., 110 respondents.

Tools Used for the Measurement of the Variables: Occupational Stress Index (Srivastava and Singh, 1981) is used for measuring work-related stress. Adopted OSI consists of 38 items, each to be rated on the five-point Likert Scale. The items relate to almost all relevant components of the job life which cause stress in some way or the other, such as, Role Overload (RO), Role Ambiguity (RA), Role Conflict (RC), Unreasonable Group and Political Pressure (UGPR), Responsibility for Persons (RP), Under Participation (UP), Powerlessness (PLN), Poor Peer Relations (PPR), Intrinsic Impoverishment (II), Low Status (LS) and Strenuous Working Conditions (SWC).

Limitations: The study does not consider any open distance learning (ODL) mode of educational institutes. Registrar, Principal, Teacher-In-Charge, Designated officer and Head of the Departments are considered as Administrators for the study. 


\section{Goodness of Scales}

Goodness of OSI has been reestablished through reliability, validity and normality tests.

Reliability Analysis: Cronbach alpha for OSI has been calculated for 38 items having 110 valid respondents is .904 which is much higher than 0.70 , implies that the scale is highly reliable.

Validity Analysis: Construct validity of the OSI scale is analysed with the help of Confirmatory Factor

\begin{tabular}{|l|c|c|c|}
\hline \multicolumn{1}{|c|}{ Measure } & Estimate & Threshold & Interpretation \\
\hline Chi-Square (CMIN/DF) & 2.098 & Between 1 and 3 & Excellent \\
\hline Comparative Fit Index & 0.956 & $>0.95$ & Excellent \\
\hline Standardised Root Mean Square Residual & 0.061 & $<0.08$ & Excellent \\
\hline Root-Mean Square Estimation Average & 0.100 & $<0.1$ & Acceptable \\
\hline P-Close & 0.031 & $>0.05$ & Acceptable \\
\hline * Adopted from Gaskin, J. \& Lim, J. (2016) & & & \\
\hline
\end{tabular}

Analysis (CFA). Two variables with poor loadings for the construct - UP and PLN - are removed from the study to satisfy validity measures. Model fit measures depicted in Table 2 shows that all the measurement indices fit well except Root-Mean Square Estimation Average which has just been accepted.

Normality Test of Stress Score: Output variable representing Work Stress is termed as 'Stress Score' computed summing up all the item-response score of selected eight OSI variables. Descriptive statistics for the Stress Score shows Mean is 97.63 (with Standard Error 1.7) with Standard Deviation 18.163, Skewness 0.122 and kurtosis -0.568 . Therefore, Stress Score is slightly negatively skewed and platykurtic in nature.

Diagram 1 shows the histogram and corresponding normal distribution for total stress score. Shapiro-Wilk test result shows that P-value $=0.262$ (statistic $=0.985$ with 110 degree of freedom) and therefore null hypothesis that the stress score is normal is accepted at 0.05 level of significance.

Table 3: Percentage Distribution of Stress-Level

\begin{tabular}{|l|c|c|c|}
\hline \multirow{2}{*}{ Work Position } & \multicolumn{3}{|c|}{ Level of Stress (\%) } \\
\hline Administrator & Low & Moderate & High \\
\hline Teacher & 20.51 & 48.72 & 30.77 \\
\hline Total & 14.08 & 54.93 & 30.99 \\
\hline
\end{tabular}

Component Bar Chart (in Percentage)

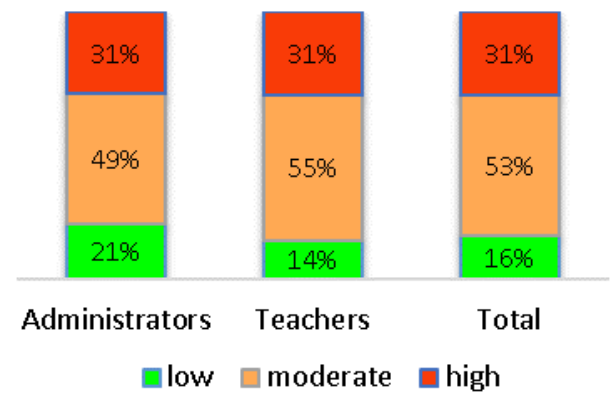

Diagram 1: Normal Curve and Histogram for Stress Score

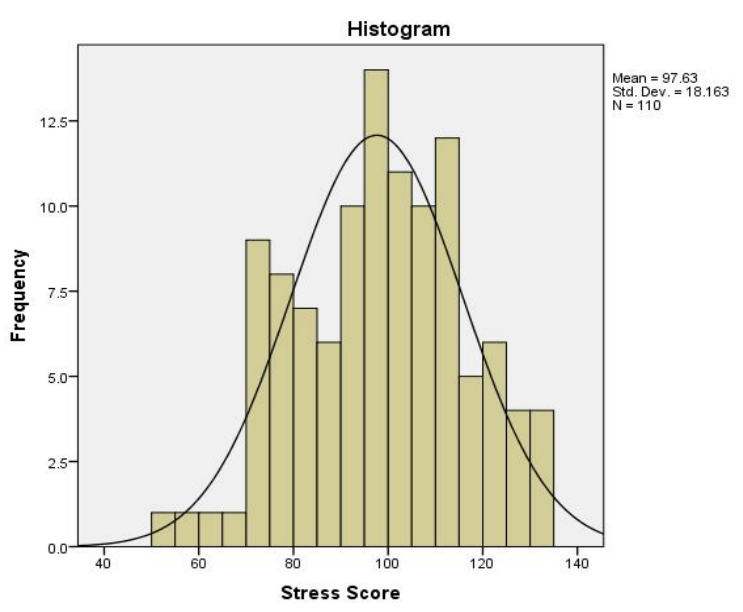

Analysis:

Respondents are categorized to high, moderate and low levels of stress groups according to the norms designed by the OSI for the output variable, total stress score. Table 3 displays the nature of stress ((Objective 1) in two parts - (i) frequency distribution and corresponding percentage distribution, and (ii) graphical presentation for the same through a component bar chart. Distribution of Stress Score shows that $31 \%$ of the respondents fall under high stress group whereas only $16 \%$ employees belong to low stress group. Distribution pattern for the Administrators and Teachers are alike. Teachers are experiencing more moderate to high level of stress than the 
administrators.

Analysis of Variance (ANOVA) is applied to test the hypothesis for each demographic and job attribute (Objective 2). Results obtained from the ANOVA (calculation is not shown to conserve space) are summarized in Table 4.

\begin{tabular}{|c|c|c|c|c|c|}
\hline \# & Test Variable & $\begin{array}{l}\text { Significant } \\
\text { Variable }\end{array}$ & $\begin{array}{l}\text { P-value of Levene } \\
\text { Statistic }\end{array}$ & F-Value & P- Value \\
\hline 1 & Gender & $\begin{array}{l}\text { UGPR } \\
\text { SWC }\end{array}$ & $\begin{array}{l}0.206 \\
0.041\end{array}$ & $\begin{array}{l}6.700 \\
4.681^{*}\end{array}$ & $\begin{array}{l}.011 \\
.019^{\#}\end{array}$ \\
\hline 2 & $\begin{array}{l}\text { Age-group } \\
\text { (Young/Middle/Post-Middle) }\end{array}$ & $\begin{array}{l}\text { RO } \\
\text { RA } \\
\text { UGPR } \\
\text { PPR } \\
\text { II } \\
\text { SWC } \\
\text { Stress Score }\end{array}$ & $\begin{array}{l}0.268 \\
0.569 \\
0.301 \\
0.972 \\
0.384 \\
0.132 \\
0.178\end{array}$ & $\begin{array}{l}4.952 \\
3.509 \\
3.882 \\
4.175 \\
5.396 \\
2.868 \\
5.607\end{array}$ & $\begin{array}{l}.009 \\
.033 \\
.024 \\
.018 \\
.006 \\
.061 \\
.005\end{array}$ \\
\hline 3 & Work-Position & RO & 0.863 & 3.805 & .054 \\
\hline 4 & $\begin{array}{l}\text { Service Experience } \\
\text { (Three groups) }\end{array}$ & $\begin{array}{l}\text { RA } \\
\text { UGPR } \\
\text { Stress Score }\end{array}$ & $\begin{array}{l}0.857 \\
0.560 \\
0.375\end{array}$ & $\begin{array}{l}3.242 \\
4.728 \\
3.170\end{array}$ & $\begin{array}{l}.043 \\
.011 \\
.046\end{array}$ \\
\hline 5 & Marital Status & RA & 0.310 & 4.388 & .015 \\
\hline 6 & Job Status & $\begin{array}{l}\mathrm{RO} \\
\mathrm{II}\end{array}$ & $\begin{array}{l}0.277 \\
0.903\end{array}$ & $\begin{array}{l}2.962 \\
4.383\end{array}$ & $\begin{array}{l}.056 \\
.015\end{array}$ \\
\hline 7 & Additional Responsibilities & Nil & - & - & - \\
\hline 8 & Area of Residence & $\begin{array}{l}\text { RO } \\
\text { RC } \\
\text { UGPR } \\
\text { PPR } \\
\text { LS } \\
\text { Stress Score }\end{array}$ & $\begin{array}{l}0.456 \\
0.959 \\
0.389 \\
0.964 \\
0.710 \\
0.586\end{array}$ & $\begin{array}{l}3.307 \\
3.592 \\
3.082 \\
3.198 \\
3.524 \\
4.704\end{array}$ & $\begin{array}{l}.040 \\
.031 \\
.050 \\
.045 \\
.033 \\
.011\end{array}$ \\
\hline 9 & Income & LS & 0.236 & 2.800 & .044 \\
\hline 10 & $\begin{array}{l}\text { Educational Qualification } \\
\text { ( PhD and Non-PhD) }\end{array}$ & PPR & 0.920 & 5.287 & .023 \\
\hline 11 & Status in Family & Nil & - & - & - \\
\hline \multicolumn{6}{|c|}{ Test of Hypotheses (Univariate: Stress Score) } \\
\hline 12 & $\begin{array}{l}\text { Work-Position and Service } \\
\text { Experience }\end{array}$ & $\begin{array}{l}\text { Corrected Model } \\
\text { Service } \\
\text { Experience } \\
\text { Work Position } \\
\text { Service } \\
\text { Exp*Work } \\
\text { Position }\end{array}$ & 0.645 & $\begin{array}{l}2.472 \\
3.544 \\
5.054 \\
2.049\end{array}$ & $\begin{array}{l}.037 \\
.032 \\
.027 \\
.135\end{array}$ \\
\hline \multicolumn{6}{|c|}{ \# Brown-Forsythe Test } \\
\hline
\end{tabular}

ANOVA results exhibited in Table 4 have identified the significant stress variables for which the mean scores of each test variable across different sub-groups significantly differ. Levene's test ensures equality of error variance for all the resultants except Strenuous Working Condition under test variable Gender (SI. No 2). In this case, Brown-Forsythe Test is applied. For serial number 12, univariate analysis is applied to test the combined effects of service experience as well as Work Position (classified into Teachers or 
Administrators) considering the Stress Score as dependent variable. Results obtained in the Table 4 are discussed in the next section - Findings and Discussion.

\section{Findings and Discussions}

Finding 1: Male and Female employees differ significantly in Unreasonable Group and Political Pressure and Strenuous Working Condition.

There is no difference of overall stress experience between the males and female members except UGPR and SWC. Female employees seems less capable of adjusting group political pressure and less congruent to strenuous working condition in comparison to their male counterparts. Investigation whether occupational stress is gender-biased, reflects variant responses (Bhuin, 2016). Therefore, experience to occupational stress is not definite for sex differentiation.

Finding 2: Young, Middle-aged, Post-Middle-Aged employees differ significantly in Role Ambiguity, Role Overload, Unreasonable Group and Political Pressure, Intrinsic Impoverishment, Strenuous Working Condition and overall stress experience.

Age has a significant role on experiencing work-stress. Results find that middle-aged group is experiencing higher stress than the young and post-middle-aged group. Post-middle-aged members, like young, are more capable of coping up job stress. The result is similar to the study of Olaitan et. al. (2010) who found that the difference of work stress was significant for ages. Studies on teachers found that stress components are negatively associated with age (Young et al., 2013; N. Quaser, 2001). However, the results of Chang and Tseng (2009) found that that the stress of younger academic heads is significantly higher than that of senior heads. Lath S.K. (2012) found that teachers with more age, experience more stress as compared to counterparts. Therefore, we can conclude that there exists no specific pattern of stress experience to ages.

\section{Finding 3: Teacher and Administrators differ themselves significantly in Role Overload.}

Apparently, there is no difference of work-stress between the teachers and Administrators. However, they differ in role overload at 5.5\% LOS. Teachers are experiencing little higher stress than administrators in terms of role overload. This may be due to teachers as well as administers are confronting similar work environment. Study of Nagri et. al. (2013) revealed that administrators recorded high levels of stress where workload was a major stressor. Literature on work stress distinguishing teachers and administrators in Indian context are rarely found.

Finding 4: Teacher and Administrators classified into three service-experience groups - below 10 years, 10 to 20 years and above 20 years - significantly differ in Role Ambiguity, Unreasonable Group and Political Pressure, and overall stress experiences.

The result is similar to age groups since age and experience are proportional to each other (Diagram 2). Highly experienced or low-experienced employees are less prone to work stress. Young employees having high zeal of establishing themselves at work place appear more sporting in nature. Dr. V. Abirami

Diagram 2: Means Plot for Stress Score (Age and Service Experience)

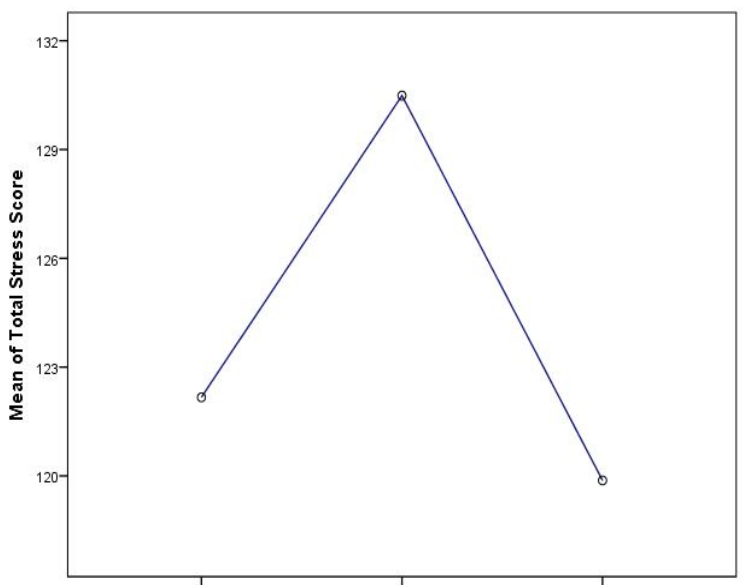

Upto 10 years Experience 11 to 20 Years Experience above20 years Experience Experience into three groups

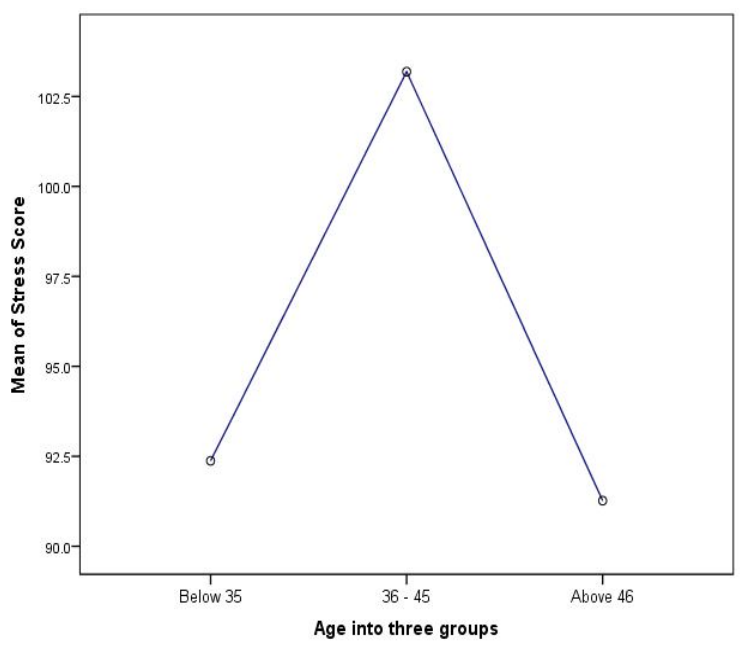


(2012) found that less-experienced teachers are experiencing more stress than their counterparts. On the other hand, Olaitan et. al. (2010) noticed the difference of work stress for work experience is not significant. We can conclude that experienced teachers and administrators are experiencing less workrelated stress.

Finding 5: Teacher and Administrators classified on the basis of marital status significantly differ in Role Ambiguity.

This is indeed an interesting outcome - unmarried members are having less stress-experience in role ambiguity than their counterparts (Diagram 3). It seems that unmarried members are more capable adjusting ambiguous task-structure than their counterparts. We have noticed that marital status differentiates overall stress experience (Nagra and Arora, 2013; Quasar, 2001).

Finding 6: Teacher and Administrators classified on the basis of job status significantly differ in Intrinsic Impoverishment and Role Overload.

Guest/visiting/part-time faculty members are experiencing more stress in terms of $\mathrm{II}$ and $\mathrm{RO}$ (significant at $6 \%$ level of significance) in comparison to regular members. This may be due to they find their jobs as monotonous and lack of autonomy. Adhoc/Probationary members are thrust upon fewer

Diagram 3: Means Plot for Role Ambiguity

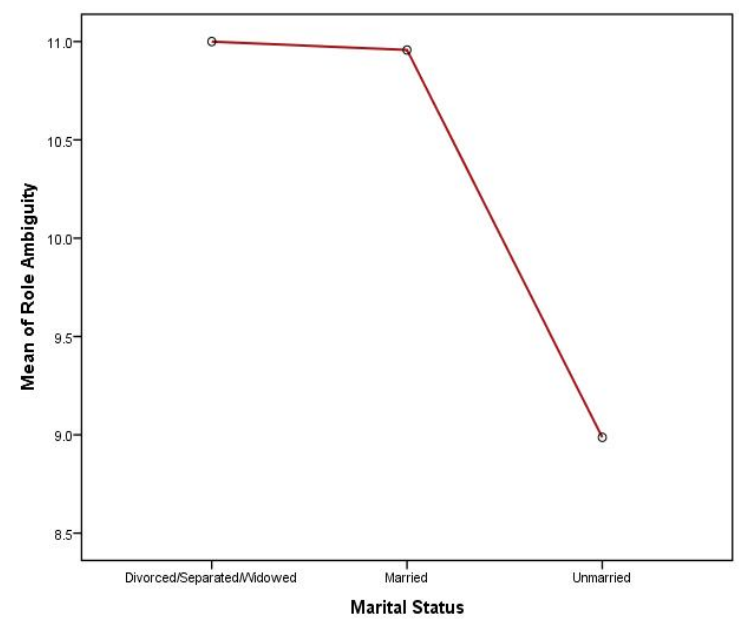
responsibilities and enjoy more autonomy in their work place than their counterparts.

Finding 7: There is no significant difference in stress experience between the Teacher and Administrators with respect to additional responsibilities.

Additional responsibilities are not contributing towards any stress differentiation. Descriptive statistics show that $70 \%$ of the respondents have undertaken additional responsibilities which may or may not be as specified in appointment letter apart from regular teaching/research work. Additional responsibilities are intrinsic to the Job Design adopted by the private management educational institutes.

Finding 8: Teacher and Administrators who reside in rural, urban or semi-urban areas significantly differ in Role Overload, Role Conflicts, Under-Group Political pressure, Poor Peer Relations, Low status and overall stress experiences.

Area of residence is found as an important significant factor discriminating overall stress experiences.

Diagram 4: Means Plot for Stress Score

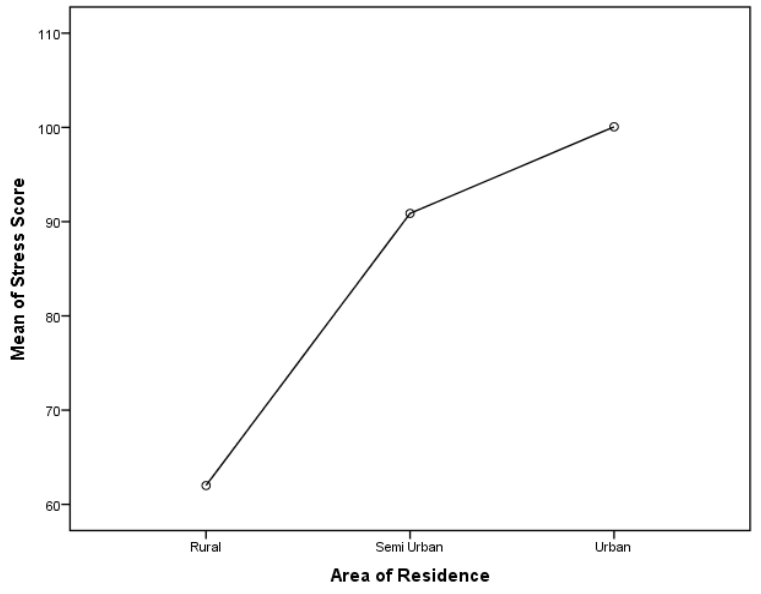

Results show that urban employees are more stressed comparing to the rural and semi-urban residents (Diagram 4). The results confirm the connotation that urban life being complex in nature has a substantial influence on work-stress.

Finding 9: Teacher and Administrators classified with respect to income significantly differ in Low Status.

Salary is an important determinant of work-life. It is a motivator as well as hygiene factor. Inadequate salary is the primary factor causing stress (Olaitan et. al., 2010; Jagdeesh, 2013; Padurarau, 2014). However, numerous studies found that income is not a significant factor of work stress. Current study shows that salary do not differentiate significantly work-related stress experiences but to LS. Results 
show that employees with low salary bracket score high in LS than other income groups. The result is congruent with the reality. Low salaried employees presume low social status in the work place than others. Strikingly, employees with highest salary also feel that their status is not aligned what they deserve.

Finding 10: Educational Qualification is not causing stress differentiations. Teacher and Administrators grouped by PhD/Non-PhD holders significantly differ in Poor Peer Relationship.

Current research reveals that educational qualifications have no influence on work stress differentiation. N. Quaser (2001) found that qualification do influence stress. But, adequate literature in Indian context on the same relationship has not been traced out.

When employees are categorized into $\mathrm{PhD}$ and Non-PhD holders, we find that they significantly differ in PPR. PhD holders have better peer relations than non-PhD holders. This may be due to doctorates are more supportive towards their colleagues than others.

Finding 11: There is no significant difference in stress experience between the Teacher and Administrators with respect to status in family.

Status in family is considered as either member or head of their own family. Head of the family incurs more family pressure than the member. Results show that no stressor is significantly distinguished by the family membership. Study by Anita S.K. (2011) found that job satisfaction among respondents was influenced by both family role stressor and work role stressors. However, no similar studies in Indian context can argue for the similar results.

\section{Finding 12: Teachers with administrators differ themselves in work stress with respect to Service experience}

Service experience is differentiating teachers with administrators in stress experience significantly. Profile plot of the interactive model shows that as service experience increases, the difference of overall stress experience in between the teachers and administrators gets widen (Diagram 5). Teachers are more or less rigid in experiencing stress whereas experienced administrators perceive low level of stress. Less experienced teachers as well as administrators do not differ much in work stress.

Hawng (1999) observed that faculty members who have been working in administrative positions for fewer than two years experienced higher levels of stress deriving out interpersonal relationships than those who have worked in such positions for $2-5$ years or 11-20 years.

\section{Conclusion}

Present study reveals that work-related stress prevails in alarming stage among the teachers and administrators engaged in privately managed BSchools in West Bengal having a strong inclination towards moderate to high level of stress. Primarily, authority must recognize the presence of work stress among the teachers and academic administrators by its intensity and virtue.

Unreasonable Group Political Pressure (influenced by Gender, Age, Service Experience and Area of Residence), Role Overload (influenced by Age, Work Position, Job Status and Area of Residence) and Role Ambiguity (influenced by Age, Service Experience and Marital Status) are three important stressors in differentiating various demographic and work groups. Institutions can mark up the sources of office 
politics and focus on building strong informal networks, power-balance and train the employee to govern their behaviour. Among the role stressor, there are two major concerns - Role Overload and Role Ambiguity. Role overload may arise due to inadequate staffing or multi-level task assignment at a time. Faculty members are forced complying more than one assignment simultaneously which brings time pressure and fear of failure. There need to provide the employees greater sense of control and job enrichment. Role Ambiguity is simply outcome of unclear roles. The role of a teacher is complex since it involves understanding the roles to be performed in each academic settings, like, inside/outside the classroom, readiness of students, subjects, instructional objectives, socialization and different administrative set up. Training on educational psychology and teaching methodology can mitigate the issue of ambiguity to a large extent.

Other significant stress issues like Intrinsic Impoverishment, Strenuous Working Condition, Poor Peer Relations, Low status and Role Conflicts, specific to selected groups, can be handled in a case to case basis. Univariate analysis shows that service experience significantly differentiates teachers with administrators in experiencing work-stress. Experience has appeared as an important human factor in designing organizational structure and playing role of administrative position of an academic institute.

\section{Reference:}

Abirami, D. V. (2012). Levels of stress among college teachers with reference to Coimbatore District. Research World , III (4(2)), 93-104.

Ahamed, S. S., \& Nair, D. S. (2014). Globalization and Management Education in India: Emerging Change Forces. International Journal of Applied Services Marketing Perspectives, 3 (1), 778 - 782.

Annual Report 2012-13, HED, Govt. of West Benagal

Bhuin, P. K. (2016). Is Teaching Stressful? A review of literature on global higher education sector. Asian Journal of Management Research, 6(3), 599-609.

Blackburn, R. T., et. al. (1986). University Faculty and Administrator Responses to Job Strains. Research in Higher Education, 25(1), 31-41

Crump, J. H., Cooper, C. L., \& Smith, M. (1980).Investigating occupational stress: a methodological. Journal of Occupational Behaviour, 1(3), 191-204.

Daftuar, C.N. (1988). A Scale of Organisational Effectiveness. In D.M. Pestonjee (ed.).Second Handbook of Psychological and Social Instruments. New Delhi: Concept.

Devi, A.N.V., \& Velayudhan, A. (2000).Job satisfaction of Women Labourers working in Private and Government Colleges. Asian Journal of Applied Psychology, 40, 25-28.

Dunham, J., (1998.), Preface. In Dunham, J. and Varma, V. (Eds), Stress in Teachers: Past, Present and Future. London: Whurr.

Jagadeesh, B., (2013), Job Stress among College Teachers: A study in Managalore Taluk of Dakshina Kannada Districts. International Journal of Organizational Behaviour \& Management Perspectives, 2 (3), 511-513.

Guglielmi R. S. \& Tatrow, K. (1998) Occupational Stress, Burnout, and Health in Teachers: A Methodological and Theoretical Analysis. Review of Educational Research, 68(1), 61-99.

Hawng, I. L. (1999). Study of elementary school part-time administrative teachers' workload pressure and their methods of accommodation. Unpublished Master's thesis, Pingtung University of Education.

Kapoor, S. (2011). Study on the Relationship of Work Related Stress on Organisational Effectiveness. International Journal of Research in Commerce and Management, 2 (8), 77-80.

Kayastha, D. P., \& Kayastha, R. (2012). A study of Occupational Stress on Job Satisfaction among Teachers with particular reference to Corporate, Higher Secondary School of Nepal: Empirical Study. Asian Journal of Management Science and Education, 1(2), 52-62.

Krishnaswamy, K. N., Sivkumar, A. I., \& Mathirajan, M. (2007). Management Research Methodology - Integration of Principles, Methods and techniques. Noida (U.P.): Pearson.

Kumar, S. (2015). A study on stress among teachers of self-financing engineering institutes, Senthil Kumar. Retrieved Jun 25, 2015, from Shodhganga: http://shodhganga.inflibnet.ac.in/handle/10603/37221 
Kyriacou, C. (2001). Managing teacher stress. In M. Calvert, \& J. A. Harvey (Eds.), Managing People. (pp. 91-99). Sheffield: Philip Armstrong.

Kyriacou, C. (2000). Stress-busting for Teachers. Cheltenham: Stanley Thornes.

Kyriacou, C. (1999). Challenges for educational research. British Journal of Educational Psychology, 69, 619-620.

Lath, S. K. (2012). A study of Occupational Stress among Teachers of Privately managed schools and Government schools in relation to age , gender and experiences. International Indexed \& Referred Research Journal , III (34), 78-79.

NIOSH Publication Number 99-101. (1999). Centre for disease control and prevention. Retrieved January 6, 2016, from: https://www.cdc.gov/niosh/docs/99-101/default.html

Nagra, V., \& Arora, S. (2013), Occupational Stress and Health among Teacher Educators. International Journal of Advanced Research in Management and Social Sciences, 2(8), 1-13.

Nagri, et. al. (2013). Levels of stress among Secondary School Administrators and its Implication in Education Management in Kenya. Academic Journals , 677-681.

Narayanan, L. (1996), Occupation-specific stress in the workplace: A comparative study of the United States and India (Doctoral Dissertation), Retrieved from UMI Microform Database (No. 9622253).

Olaitan, O. L. (2010). Prevalence of job stress among primary school teachers in South-west, Nigeria. African Journal of Microbiology Research , 4 (5), 339 - 342.

Paduraru, M. E. (2014). Sources of Occupational Stress among University Professors- A Case Study for the Romanian Universities. Review of International Comparative Management , 15 (1), 49-56.

Quasar, N. (2011). A study of Occupational Stress Among School teachers. International Journal of Education and Allied Sciences , 2 (2), 109-124.

Reddy, G. I., \& Poornima, R. (2012). Occupational Stress and Professional Burnout among the University Teachers in South India. International Journal of Educational Planning \& Administration, 2 (2), 109-124.

Robbins, S.P., \& Sanghi S. (2006).Organizational Behavior (11ed.).New Delhi: Dorling Kindersley.

Rudow, B., (1999), Stress and Burnout in the Teaching Profession: European Studies, Issues and Research Perspectives. In R. Vandenberghe and A. Huberman (Eds.), Understanding and Preventing Teacher Burnout. Cambridge: Cambridge University Press.

Selye, H. (1956). The Stress in Life. New York: McGraw Hill.

Singh, D. P., \& Rani, S. (2015). Work Stress among College Teachers in Self-financing College: An Explorative Study. International Journal of Innovations in Engineering and Technology, 5 (2), 443-448.

Srivastava, A.K., and A.P., Singh, (1981) Construction and Standardization of Occupational Stress Index; a pilot study. Indian Journal of Clinical Psychology, 8, 133-136.

Srivastava, A. K. (1999). Management of Occupational Stress - Theories and Practice. New Delhi: Gyan Pub. House.

Tuettemann, E. \& Punch, K. F. (1992).Psychological Distress in Secondary Teachers: Research Findings and Their Implications. Journal of Educational Administration, 30(1) https://doi.org/10.1108/09578239210008817

Wilke, P., Gmelch, W. H., \& Lovrich, J. N. (1985). Stress and Productivity: Evidence of the Inverted U Function. Public Productivity Review, 8 (4), 342-356.

Xiao-Xing He, Z.-Y. L.-H.-A. (2000). A comparative study of stress among university faculty in China and Japan. Higher Education, 39 (3), 253-278.

Young, Y., Nasterlack, M., Pluto, R.-P., Lang, S., \& Oberlinner, C. (2013). Occupational stress perception and its potential impact on work ability. IOS Press (46), 347-354. 